\title{
KONTRUKSI SOSIAL DAN PENDIDIKAN ANAK DALAM KELUARGA PELAKU TERORIS
}

\author{
Arini Indah Nihayati \\ Bidang Penerangan Agama Islam, Zakat, dan Wakaf \\ Kanwil Kementerian Agama Jawa Timur \\ Email: arinimansda@gmail.com
}

\begin{abstract}
Abstrak
This article discusses the phenomenon of the widespread involvement of children in acts of terrorism in Indonesia, especially those that occurred in 2018. Such phenomenon indicates that mothers and fathers involve their children in acts of terrorism. The research is conducted with Berger and Luckman's social construction approach. In addition, Derrida's deconstruction theory is also employed to support the analysis. The result, based on Berger and Luckman's social construction theory, this phenomenon occurs because of radical constructivism. Furthermore, employing Derrida's deconstruction theory, this research finds that such terrorism has tendency of deconstruction process that rejects all forms of establishment, absoluteness, standard and rigid values in society. This proves the dynamics of human diversity in the real sense. However, this can also lead to intolerance.
\end{abstract}

Kata kunci: Terrorism, Family, Social Construction, Deconstruction.

\section{Pendahuluan}

Fenomena yang terjadi akhir-akhir ini adalah bermula dari keterlibatan individu-individu yang dikategorikan sebagai anak dalam aksi-aksi terorisme yang akhir-akhir ini terus meningkat. Keterlibatan anak dalam kegiatan teroris sungguh memprihatinkan sekali, karena anak dalam hal ini menjadi korban dari keegoisan oarag tua. Padahal dalam kasus teroris keterlibatan anak dalam kasus tindak pidana teroris merupakan korban dari jaringan, doktrin, propaganda ajakan oleh orang dewasa. Kasus hukum yang menimpa anak menjadi pertanyaan bagi peneliti seputar bagaimana transformasi sosial anak dalam keluarga teroris yang menyebabkan anak terlibat dalam gerakan teroris. Di samping itu, bagaimana proses sosialisasi anak dalam masyarakat sehingga mereka bisa terlibat dalam kegiatan teroris yang dilakukan oleh orang tua mereka. 
Menurut Mattessich dan Hill (1987), perkembangan keluarga (family development) merujuk pada proses perkembangan dan transformasi struktural yang progresif sepanjang sejarah keluarga. Terdapat tiga aspek penting untuk memahami fenomena perkembanagan keluarga; Memantapkan perkembangan keluarga sebagai organisasi dan fenomena interaksi. Menekankan hubungan atau kelangsungan perilaku keluarga sepanjang sejarah keluarga. Dan mencirikan dua sumber perkembangan perubahan, yaitu perubahan syarat fungsional dan timbulnya tekanan hidup. Point dari perspektif perkembangan keluarga adalah menjelaskan perubahan tingkatan keluarga dari waktu ke waktu (family time) yang dipercepat secara internal oleh permintaan anggota keluarga (biologis, psikologis dan kebutuhan sosial) dan yang eksternal oleh masyarakat yang lebih luas (harapan masyarakat dan keterbatasan lingkungan).

Ketika berbicara tentang korban anak-anak, maka pasal mengenai kompensasi dan rehabilitasi (pasal 36 dan pasal 38) perlu dicantumkan dengan jelas. Pencantuman hal-hal tersebut dalam revisi UU Tindak Pidana Teroris adalah penting karena karena anak-anak masih mempunyai masa depan yang panjang, dan apabila penangannya tidak komprehensif, maka upaya dan akses membawa anak-anak untuk keluar dari lingkarana gerakan radikalisme dan terorisme menjadi sulit bahkan tidak menutup kemungkinan mereka akan terlibat lebih jauh dalam gerakan tersebut.

Dari data Direkturat Jendral Rahabilitasi Sosial Kemensos Edi Suharto mengatakan saat ini terdapat 200 anak yang berada dipanti Sosial Marsudi Putera (PSMP) Handayani di Bambu Apus Jakarta Timur. Sebagian besar dari mereka dideportasi dari Turki saat terciduk hendak dibawa ke Suriah. Sebenarnya daya tamping dari PSMP Handayani hanya 100, sekarang menjadi 200 anak. Anak-anak yang mengikuti orangtuanya menebar teror di Surabaya dan Sidoarjo yang berhasil selamat berjumlah 7 
anak 3 anak laki-laki dan 4 anak perempuan. Adapun tiga anak dari pelaku teror Anton Febrianto yang meninggal di Rusunawa Wonocolo, Sidoarjo akibat bom rakitannya meledak anatar lain Ainur Rahman (15), Faizah Putri Hasanah (11), dan Hudan (11) dan Ais yang merupakan putri dari keluaga bom bunuh diri di Mapolres Surabaya. Dari ketujuh anak tersebut sekarang masih dalam pengawasan Kemensos untuk direhabilitasi sebelum dikembalikan kekeluarga. Fenomena yang mengejutkan dari peristiwa bom di Surabaya dan Sidoarjo adalah keterlibatan keluarga, perempuan dan anak dalam aksi teror tersebut. Oleh ICPW (Organisasi Perlindungan Anak Indonesia Child Protection Watch) dan pemerhati anak yang di dalamnya akan dilibatkan Kementrian Sosial (Kemensos), Kementrian Pemberdayaan Perempuan dan Perlindungan Anak, Komisi Perlindungan Anak (KPAI) Pelayanan Terpadu Pemberdayaan Perempuan dan Anak (P2TP2A).

Program layanan yang diberikan di PSMP Handayani atau panti sosial lainnya yakni bimbingan sosial, bimbingan fisik, dan mental, bimbingan ketrampilan hingga pengembangan minat dan bakat. Akan tetapi, hingga saat ini upaya yang telah dilakukan oleh pemerintah dirasa masih kurang optimal. terbukti dengan daya tampung dipanti yang melebihi kapasitas sehingga bimbingan kepada secara individu sangat kurang. Kendala lain stigma negatif yang berkembang dimasyarakat sangat menyudutkan mereka yang berada maupun bersinggungan dengan kelompok radikal dirasa sangat kuat. Pendekatan khusus terhadap pengangan anak yang bersinggungan dan berada dalam lingkungan tersebut butuh dilakukan secara khusus dan mengedepankan pendekatan yang ramah anak. Selain itu, perlu dalam kasus anak dalam radikalisme ini perlu diingat bahwa anak adalah korban. Oleh karena itu, mengadvokasi kondisi ini dalam UU Tindak Pidana Terorisme maupun perangkat hukum pendukung selanjutnya sangat diperlukan. 
Penanganan bagi anak-anak yang ada di dalam jaringan terorisme lainnya, juga belum sepenuhnya berjalan sesuai mandat Undang-Undang No. 35 tahun 2014 perubahan atas Undang-Undang No. 23 tahun 2002 tentang Perlindungan Anak. Dalam pasal 69B disebutkan, bahwa "Perlindungan khusus bagi anak korban jaringan terorisme sebagaimana dimaksud Pasal 59 ayat (2) huruf k dilakukan melalui upaya: a. Edukasi tentang pendidikan, ideologi dan nilai nasionalisme; $b$. Konseling tentang bahaya terorisme; c. Rehabilitasi sosial; dan d. Pendampingan sosial.

Teori konstrukasi yang dikemukan oleh Peter L. Berger dan Thomas Luckmann menjadi acuan untuk mengupas bagaiman kontruksi sosial itu dapat dibentuk. Kehidupan sehari-hari telah menyimpan dan menyediakan kenyataan, sekaligus pengetahuan yang membimbing perilaku sehari-hari. Kehidupan sehari-hari tersebut menampilkan realitas objektif yang ditafsirkan oleh individu atau maknamakna subjektif. Dengan demikian individu dalam hal ini anak dari pelaku teroris menjadi penentu dalam dunia sosial yang dikontruksikan berdasarkan kehendaknya. Individu berperan sebagai media produksi sekaligus reproduksi yang kreatif dalam mengkontruksi dunia sosialnya.

Kontruksi sosial adalah suatu proses pemaknaan yang dilakukan oleh setiap individu terhadap lingkungan dan aspek diluar dirinya, yaitu makna subjektif dari realitas objektif didalam kesadaran orang yang menjalani aktivitas kehidupan seharihari. Oleh karena itu dalam makalah ini lebih memfokuskan bagaimana prespektif Konstruksi Sosial Burger dan Luckman dalam filsafat ilmu? Dan bagaimana agama dalam dekontruksi Derrida di era postmodern?.

\section{Pembahasan}

\section{Teror, Pemuda, dan Keluarga}

Selama ini, sudah banyak studi tentang terorisme yang dikaitkan dengan faktor-faktor lain di sekelilingnya. Jurnal yang ditulis oleh 
Rosliawati Taib (2017) berjudul Political Particaption: Radical Young People in Malaysia adalah salah satu di antaranya. Artikel ini berisi tentang perjuangan politik generasi muda radikal di Malaysia yang telah berevolusi sejak masa awal perjuangan masyarakat demi negara untuk mencapai tanduk kemerdekaan dari pemerintahan kolonialisme.

Perjuangan mereka akhirnya mengarah pada kebebasan negara dari belenggu imperialisme. Selanjutnya, gerakan politik pemuda Malaysia berutang budi kontribusi melalui upaya mereka untuk memenuhi kebutuhan mayoritas dalam masyarakat yang dikenal oleh pemerintah. sehingga kebutuhannya bisa diatasi oleh pemerintah. Pola dan tren gerakan anak muda sejak kemerdekaan menunjukkan bahwa partisipasi mereka dimotivasi oleh tujuan tertentu. Gerakan pemuda Malaysia dimulai dengan demonstrasi damai tetapi berevolusi menjadi radikalisme selama bertahun-tahun karena beberapa faktor. Diskusi tentang gerakan politik pemuda Malaysia sejak era kolonial telah berfokus pada konflik dramatis dan pengaruh kekerasan politik internasional yang dipicu oleh rezim otokratis.

Sebagai akibat dari pemerintahan yang opresif dari pemerintah, orang-orang membalas melalui pemberontakan dan demonstrasi yang kejam dengan tujuan akhir untuk memaksa pemerintah mengubah caracaranya atau untuk menggulingkan rezim yang dianggap tidak manusiawi, tidak adil dan menindas mereka. Dalam pandangan ini, radikalisme politik lokal dianggap sebagai ukuran yang dapat dibenarkan tidak hanya untuk mengantar perubahan struktural yang diinginkan untuk rakyat, tetapi juga untuk berfungsi sebagai peringatan bagi mereka yang berkuasa bahwa rakyat tidak akan berdiam diri dalam ketidakpedulian ketika di bawah penindasan, sebaliknya mereka akan bangkit sebagai pembalasan jika hak-hak mereka telah terancam sebagaimana disaksikan dalam beberapa pemberontakan politik rakyat di beberapa negara. Kekerasan politik yang meletus di negara-negara Eropa 
Barat pada abad ke-19 yang mempengaruhi Rusia, Prancis, Italia, dan Spanyol tampaknya kembali terulang ketika kekerasan politik mulai berkecamuk di kota-kota besar (Daniel Ross, 2004). Letusan politik terjadi karena adanya perlawanan rakyat terhadap pemerintah karena telah meminggirkan kebutuhan rakyat, menyebabkan banyak orang merasa bahwa mereka telah dikesampingkan secara ekonomi. Ketidakpuasan ini mungkin menyebabkan orang-orang terlibat dalam protes dan demonstrasi melawan pemerintah. Gerakan politik dapat mengkibatkan dampak yang lebih merusak jika masyarakat terlibat dalam konspirasi internasional yang bertujuan untuk menjatuhkan pemimpin sasaran atau pun partai yang sedang berkuasa.

Ketika mengobserbasi kasus kekerasan politik internasional pada era kontemporer ini, perlu dicatat bahwa kelompok kelas menengah adalah pihak yang menjadi ujung tombak kekerasan politik yang terjadi di Jepang, Uruguay, Amerika Serikat dan Jerman karena pemuda dari kelompok kelas menengah telah banyak memproduksi lulusan-lulusan yang terpengaruh konsep dasar keadilan sosial (Hobsbawm, 1973, hal 221). Palestina, Irlandia Utara, Sri Lanka, Kashmir, Punjab, Bosnia, dan Sudan telah menghadapi tahap lokal dari konflik etnik yang terjadi selama lebih dari 15 tahun terakhir. Namun, konflik-konflik etnik telah tertanam melalui praktik sistem politik plural dan pembangunan ekonomi di negara-negara industri Eropa Barat. Praktik sistem politik demokratis dirancang untuk mengatasi masalah radikalisme politik yang meletus karena kelemahan dalam sistem itu sendiri, melalui ketentuan konstitusional dari hak dan kebebasan berbicara, partisipasi yang setara untuk semua, hak untuk memilih dalam pemilihan dan dll. Namun, sistem demokrasi tidak menjanjikan bahwa kekerasan politik tidak akan terjadi di negara ini. Bahkan, ada beberapa argumen di kalangan cendekiawan yang mengklaim bahwa demokrasi dapat menjadi jalan yang mengarah pada kekerasan politik internasional, sebagaimana 
dibuktikan dalam kasus-kasus kekerasan politik yang telah terjadi di negara-negara demokratis yang meliputi India, Thailand, Amerika Serikat, dan Sri Lanka.

Ada juga tulisan yang menggambarkan kondisi terteror para pemuda dan institusi keluarga di masyarakat, dalam kemelut konflik bersenjata yang ditulis Christine E. Merrilees (2018) berjudul The Role OfEmotional Security, Narrative, And Resilience For Youth And Families in ContextsOf Armed Conflict. Artikel ini menjelaskan tentang konflik bersenjata pada abad ke-21 yang telah berdampak pada kehidupan jutaan keluarga, menghancurkan struktur sosial masyarakat, dan, dalam banyak kasus, memaksa keluarga meninggalkan rumah dan cara hidup mereka dengan harapan menemukan keamanan dan masa depan yang menjanjikan. Keluarga yang telah mengalami konflik bersenjata menghadapi tekanan luar biasa di seluruh wilayah kehidupan, banyak di antaranya akan bertahan dengan baik melewati pelarian dari atau akhir konflik formal. Dibandingkan dengan kondisi warga sipil dalam konflik antar negara bagian yang mendominasi pada paruh pertama abad ke20, trauma ketakutan yang menentukan bentuk-bentuk perang kontemporer dialami bagi warga sipil yang sekarang menjadi korban dan sekaligus dipaksa untuk turut andil dalam dalam kekerasan (Pearson, 2002). Memahami temuan teoritis dan empiris yang muncul tentang dampak kekerasan politik pada anak-anak keluarga memberikan pelajaran penting bagi praktisi dan profesional hukum yang bekerja dengan keluarga dari komunitas ini.

Tujuan artikel ini adalah untuk meninjau dan mengevaluasi temuan penelitian terbaru mengenai pemuda dalam konteks kekerasan politik dan konflik bersenjata dengan foucs tentang interaksi antara keluarga dan fungsi masyarakat serta pengembangan pemuda. Mengingat sifat perang yang menghancurkan, banyak penelitian tentang pemuda di komunitas yang dilanda perang telah berfokus pada hasil kesehatan 
mental seperti gangguan stres pasca-trauma (PTSD), yang berhubungan dengan pengalaman mereka bersentuhan dengan kekerasan politik dan konflik bersenjata (Barber \& Schluterman, 2009). Baru-baru ini bahwa pendekatan yang lebih luas telah diambil yang meneliti hasil remaja lainnya, seperti sikap antarkelompok, perilaku prososial, keterlibatan sipil, dan proses, risiko dan faktor pelindung yang menjelaskan hasil ini (Cunning, Merriless, Taylor \& Mondi, 2017a).

Dalam uraian berikut, kami secara singkat menggambarkan sifat konflik bersenjata kontemporer dan berbagai pengalaman yang ditemukan oleh keluarga dan remaja dalam konteks ini. Kami kemudian memfokuskan peninjauan pada penelitian yang secara khusus menguji proses keluarga dan masyarakat yang cenderung memberi implikasi pada pengembangan pemuda dalam konteks ini. Yang terkandung dalam perbincangan tentang hal ini adalah pengakuan atas peran narasi sejarah dan budaya dalam transmisi integratif atas dampak kekerasan politik pada keluarga dan pemuda. Artikel ini diakhiri dengan rekomendasi umum untuk praktisi pengadilan keluarga yang bekerja dengan keluarga yang mengalami kekerasan politik di komunitas mereka.

Temuan menunjukkan bahwa paparan konflik bersenjata mempengaruhi pemuda, keluarga, dan komunitas di berbagai konteks, dengan efek bencana dan jauh jangkauannya. Penelitian telah difokuskan untuk mengidentifikasi stresor yang terkait dengan paparan tersebut, dengan temuan bahwa hal itu tidak hanya terkait dengan ketidakmampuan individu untuk beradaptasi tetapi juga untuk perselisihan dalam keluarga dan komunitas mereka. Keluarga yang dilanda perang lebih rentan terhadap situasi kekerasan dan keamanan emosional mereka sering dikompromikan, yang menyerukan pendekatan yang hati-hati dan berpandangan jauh ketika berhadapan dengan mereka. Mereka yang membantu hendaknya mengingat gambaran yang lebih 
besar untuk mengukur dampak kekerasan politik terhadap stresor tingkat keluarga.

Untuk memastikan keamanan yang lebih besar dalam berbagai konteks dan bidang yang berfungsi, perawatan harus dilakukan agar dapat berfungsi di seluruh penyedia dukungan di mana pun yang memungkinkan. Selain itu, seperti yang disarankan Wessells (2017), penyediaan dukungan sistematis dalam banyak domain (seperti kebutuhan dasar dan kesehatan mental) meningkatkan rasa aman dengan memenuhi kebutuhan keluarga yang terkena dampak konflik bersenjata dan pada akhirnya membuat mereka merasa didukung di setiap tingkat. Penelitian ini berfokus pada mengidentifikasi faktor-faktor yang menjelaskan berbagai hasil kekerasan politik, dengan temuan yang menunjukkan bahwa konflik bersenjata mengancam rasa keamanan pemuda. Hal ini dipengaruhi oleh persepsi dan keyakinan individu dan konteks sosial yang lebih luas. Memastikan bahwa orang-orang muda ini merasa aman di setiap tingkat yang mungkin dapat membantu mencegah hasil yang merugikan seperti agresi dan depresi.

Singkatnya, penelitian terkini tentang dampak konflik bersenjata dan kekerasan politik pada keluarga dan kaum muda menunjukkan keterkaitan keluarga, fungsi masyarakat, dan perkembangan pemuda. Hasil jangka panjang dan negatif ini telah didokumentasikan dengan baik, dan kita sekarang harus mengalihkan perhatian kita untuk mengidentifikasi proses yang mendasari yang akan mendorong pemulihan dan lintasan jangka panjang kesejahteraan. Dukungan harus didasarkan pada pemahaman yang baik tentang latar belakang budaya, dengan hati-hati untuk tidak overgeneralisasi pada pola atau pun meremehkan pemuda beserta kemampuan beradaptasi mereka, dan harus ada pemahaman tentang berbagai konteks dan kebutuhan untuk merasa didukung di dalamnya. Karena kerumitan konflik bersenjata kontemporer, membantu pemuda, keluarga, dan komunitas yang terkena 
dampak tidak dapat dicapai tanpa memahami berbagai konteks di mana mereka tinggal. Titik awal bantuan ini berasal dari pemahaman tentang keterkaitan konteks-konteks ini dan keyakinan kuat dalam mendorong kemampuan beradaptasi pemuda melalui dukungan yang konsisten dan sistematis. Ketika praktisi dan profesional hukum yang bekerja dengan keluarga dari komunitas yang terpengaruh perang mengingat semua poin ini dalam pikiran dan memberikan dukungan di banyak domain, mereka dapat membantu meningkatkan keamanan emosional kaum muda dan pada akhirnya membantu mereka dalam mengadopsi ketahanan dan kemampuan mengatasi masalah yang lebih besar.

Ada pula penelitian yang ditulis oleh Dr. Avital Laufer (2017) berjudul Children's Emotional and Behavioral Problems in The Shadow of Terrorism: The Case of Israel. Penelitian ini menginvestigasi kesejahteraan anak-anak yang bersentuhan terlalu lama dengan serangan rudal. Dilakukan sebuah studi tentang gejala pascatrauma, tekanan emosional, dan masalah perilaku di antara 152 anak-anak dari Israel selatan, sebuah daerah yang rentan terhadap serangan rudal. Gejala pasca-trauma dinilai dengan Indeks Reaksi Gangguan Stres Pascatrauma untuk Anak-anak (CPTS-RI) versi self-reported. Masalah emosional dan perilaku dinilai dengan menggunakan Child Behavioral Checklist (CBCL), dengan bantuan para ibu. Para ibu tersebut diminta untuk menjawab CBCL mengenai perilaku anak-anak mereka, baik di masa sekarang dan sebelum serangan rudal.

Dalam perang kontemporer, wilayah sipil tidak dipisahkan dari zona konflik. Oleh karena itu, sangat penting untuk mengevaluasi keadaan emosional anak-anak ketika terus menerus terkena ancaman keamanan. Intervensi terapeutik sangat penting untuk kelompok populasi yang mengalami ancaman keamanan yang berkepanjangan. Hal ini harus dipandu oleh para profesional, para ahli yang mampu memandu interpretasi peristiwa anak-anak serta menawarkan bimbingan orang tua. 
Meningkatkan kesadaran orang tua mengenai pengaturan emosi anakanak mereka adalah tujuan yang penting dan patut dipuji. Karena hal tersebut dapat memengaruhi kemampuan anak-anak dalam mengatur emosi mereka dan mengatasi berbagai situasi yang menantang. Sebagai hasilnya, strategi regulasi emosional mereka dapat ditingkatkan (lihat PatHorenczyk et al., 2015). Memang, sudah jelas bahwa pengaturan emosi anak-anak sangat dipengaruhi oleh hubungan mereka dengan orang tua mereka (Pat-Horenczyk et al., 2015; Guttman-Steinmetz et al., 2012, Shechory Bitton, 2013).

Menurut penelitian ini pada populasi orang dewasa (Stein et al., 2017), kontak langsung terhadap peristiwa penembakan yang sedang berlangsung dikaitkan dengan lebih banyak ketahanan, menunjukkan efek habituasi terhadap stres traumatik yang berkelanjutan. Namun, kontak langsung dengan serangan roket yang terjadi terus menerus dan terus berlangsung, akan memberi dampak pada masalah perilaku dan sosial dalam skala yang luas pada anak-anak belum mendapat perhatian yang cukup (Shechory Bitton, 2013). Selain itu, ada indikator yang menunjukkan bahwa habituasi terhadap penembakan yang sedang berlangsung tidak mengurangi gejala pribadi (Stein et al., 2017). Jadi setiap pemeriksaan efek ancaman keamanan pada kesejahteraan anak harus membedakan antara kontak langsung satu-waktu dengan yang berkepanjangan serta dimensi lain dari ancaman.

Tingkat ancaman emosional (yaitu, ketakutan) adalah salah satu dimensi serangan yang penting. Ancaman keamanan yang menghasilkan tingkat ketakutan yang lebih tinggi menghasilkan lebih banyak efek negatif - bahkan jika serangan tidak terjadi di dekat anak-anak. Tingkat ketakutan dapat menjadi prediktor kuat tekanan emosional daripada kedekatan fisik atau sosial dengan serangan (Laufer \& Solomon, 2009; Shechory Bitton, 2013; Solomon \& Lavi, 2005). Namun demikian, 
kedekatan fisik dan sosial sangat penting untuk menilai efek dari ancaman keamanan pada anak-anak

(Scrimin et al., 2011; Thabet et al., 2016; Thabet, Tawahina, Sarraj \& Vostanis, 2008). Kenyataannya, kedekatan fisik yang lebih besar dengan serangan rudal dan kedekatan sosial dengan seseorang yang dipengaruhi oleh tindakan itu menghasilkan efek negatif yang lebih kuat pada kesejahteraan anak.

Sejak penarikan Israel dari Gaza pada 2005, "komite-komite amplop Gaza" semakin menderita karena serangan roket yang konsisten. Termasuk pada kota Negev barat Sderot serta banyak Kibbutzim dan Mosaik. Komunitas-komunitas ini mengalami penembakan dengan volume tinggi. Sebanyak 401 peluru roket diluncurkan di daerah amplop ini pada tahun 2005, dengan jumlah meningkat menjadi 1722 pada tahun 2006, 1276 pada tahun 2007, dan 2048 pada tahun 2008. Pada tahun 2009, ketika data dikumpulkan, jumlah perisai telah diturunkan menjadi 569 (Agen Keamanan Israel, 2014).

Sementara itu, ada banyak bukti yang menunjukkan sentralitas hubungan orangtua-anak dalam penyesuaian emosional dan perilaku anak. Namun, orang tua dan anak-anak mungkin akan membedakan persepsi mereka tentang dimensi pengasuhan orang tua (misalnya perawatan dan kontrol). Sebagai contoh, sementara orang tua mungkin menganggap perawatan dan dukungan yang mereka berikan untuk anakanak mereka telah optimal dan cukup, anak-anak itu sendiri, sebagai penerima perawatan dan dukungan ini, mungkin yang merasa berbeda, yaitu tidak optimal dan tidak cukup, tentu saja, begitu juga sebaliknya. Fakta itu dikemukakan Gali Tangir (2017) dalam penelitiannya yang berjudul Children's Ajustment in a Climate of Political Violence: Comparing Mother and Child Reports.

Persepsi yang berbeda ini muncul karena berbagai alasan, seperti kesalahpahaman atau salah tafsir orang tua terhadap kebutuhan dan 
tingkah laku anak, atau ekspektasi anak terhadap orangtuanya yang menyimpang dari apa yang diberikan oleh orang tua. Memahami apakah penyesuaian diri seorang anak lebih terkait erat dengan laporan anak atau laporan orang tua tentang perawatan dan kontrol ibu, dapat membantu peneliti dalam menentukan cara optimal untuk mengumpulkan data di antara populasi ini. Dengan kata lain, satu keuntungan dapat ditingkatkan efisiensinya (mengingat waktu yang terbatas untuk mengumpulkan data, melakukannya hanya melalui satu laporan-entah orang tua atau anak akan lebih menghemat waktu) sementara keuntungan lainnya.

Hasil penelitian menunjukkan bahwa baik ibu dari anak perempuan maupun anak perempuan itu sendiri melaporkan tingkat perawatan yang lebih tinggi, dibandingkan dengan ibu dari anak laki-laki dan anak laki-lakinya, sementara ibu dari anak laki-laki dan anak laki-laki melaporkan kontrol yang lebih tinggi. Kontrol ibu yang lebih tinggi, seperti yang dilaporkan oleh anak, dikaitkan dengan PTSS yang dilaporkan sendiri oleh anak. Kontrol ibu yang lebih tinggi, seperti yang dilaporkan oleh ibu, dikaitkan dengan kesulitan total anak. Namun, perawatan ibu, baik yang dilaporkan oleh ibu atau pun anak, tidak ditemukan keterkaitannya dengan penyesuaian diri anak. Anak-anak usia sekolah dan ibu mereka sepakat tentang dimensi maternal dan kontribusi mereka terhadap penyesuaian anak.

\section{Perspektif Konstruksi Sosial Burger dan Luckman}

Suatu proses pemaknaan yang dilakukan oleh setiap individu terhadap lingkungan dan aspek diluar dirinya terdiri dari proses eksternalisasi, internalisasi dan objektivasi. Eksternalisasi adalah penyesuaian diri dengan dunia sosiokultural sebagai produk manusia, objektivitas adalah interaksi sosial dalam dunia intersubjektif yang dilembagakan atau mengalami proses instutusionalisasi, dan internalisasi adalah individu mengidentifikasi diri ditengah lembaga-lembaga sosial dimana individu tersebut menjadi anggotanya. 
Istilah kontruksi sosial atas realitas (social contruction of reality) didefinisikan sebagai proses sosial melalui tindakan dan interaksi dimana individu menciptakan secara terus-menerus suatu realitas yang dimiliki dan dialami bersama secara subjektif. Asal usul kontruksi sosial dari filsafat Kontruktivisme yang dimulai dari gagasan-gagasan kontruktif kognitif. Menurut Von Glasersfeld, pengertian kontruktif kognitif muncul dalam tulisan Mark Baldwin yang secara luas diperdalam dan disebarkan oleh Jean Piaget. Namun apabila ditelusuri sebenarnya gagasan pokok Kontruktivisme sebenarnya telah dimulai oleh Giambatissta Vico, seorang epistemology dari Italy, ia adalah cikal bakal Kontrukvisme.

Dalam aliran filsafat, gagasan kontruktivisme telah muncul sejak Socrates menemukan jiwa dalam tubuh manusia, sejak Plato menemukan akal budi dan ide. Gagasan tersebut semakin lebih konkret lagi setelah Aristotales mengenalakan istilah, informasi, relasi, individu, subtansi, materi, esensi dan sebagainya.Ia mengatakan bahwa manusia adalah makhluk sosial, setiap pernyataan harus dibuktikan kebenarannya, bahwa kunci pengetahuan adalah fakta Aristotales pulalah yang telah memperkenalkan ucapannya 'Cogito ergo sum' yang berarti "saya berfikir karena itu saya ada". Kata-kata Aristotales yang terkenal itu menjadi dasar kuat bagi perkembangan gagasan-gagasan kontruktivisme sampai saat ini.

Pada tahun 1710, Vico dalam 'De Antiquissima Italorum Sapientia' mengungkapkan filsafatnya dengan berkata 'Tuhan adalah pencipta alam semesta dan mansia adalah tuan dari ciptaan. Dia menjelaskan bahwa "mengetahui" berarti mengetahui bagaimana membuat sesuatu ini berarti seseorang itu baru mengetahui sesuatu jika ia menjelaskan unsur-unsur apa yang membangun sesuatu itu. Menurut Vico bahwa hanya dai yang tahu bagaimana membuatkanya dan dari apa ia membuatnya, sementara itu orang hanya dapat mengetahui sesuatu yang telah dikontruksikannya. 
Sejauh ini ada tiga macam kontruktivisme yaitu kontruktivisme radikal, realism hipotesis dan kontruktivisme biasa. Kontruktivisme radikal hanya dapat menagkaui apa yang dibentuk oleh pikiran kita. bentuk itu tidak selalu representasi dunia nyata. Kaum kontruktivisme radikal mengesampingkan hubungan antara pengetahuan dan kenyataan sebagai suatu kreteria kebenaran. Pengetahuan bagi mereka tidak merefleksi sautu realita ontologism objektif, namun sebuah realitas yang dibentuk oleh pengalaman seseorang. Pengetahuan selalu merupakan kontruksi dari individu yang mengetahui dan tidak dapat ditransfer kepada individu lain yang pasif karena itu konstruksi harus dilakukan sendiri olehnya terhadap pengetahuan itu, sedangakan lingkungan adalah sarana terjadinya kontruksi itu. Realisme hipotesis, pengetahuan adalah sebah hipotesis dari struktur realitas yang mendekati realitas dan menuju kepada pemgetahuan yang hakiki. Kontruktivisme biasa mengambil semua konsekuensi konstruktivisme dan memahami pengetahuan sebagai gambaran dari realitas itu. Kemudian pengetahuan individu dipandang sebagai gambaran yang dibentuk dari realitas objektif dalam dirinya sendiri. Dari ketiga macam konstruktivisme, terdapat kesamaan dimana konstruktivisme dilihat sebagai sebuah kerja kognitif individu untuk menafsirkan dunia realitas yang ada karena terjadi relasi sosial antara individu dengan lingkungan atau orang disekitarnya. Individu kemudian membangun sendiri pengetahuan atas realitas yang dilihat itu berdasarkan pada struktur pengetahuan yang telah ada sebelumnya, inilah yang oleh Berger dan Luckmann disebut dengan konstruksi social.

\section{Agama dan Postmodernisme}

Term Postmodernisme pertama kali dipakai pada tahun 1870 an oleh seniman Inggris John Watkins Champman. Selanjutnya pada tahun 1971 term ini dipakai Rudolf Panwitz dengan term yang agak berbeda yaitu Post impresionisme (1880an) dan post industrial (1914-1922). Ini adalah permulaan penggunaan awalan 'post' yang kemudian bermekaran 
diawal 1960-an dalam literature, pemikiran sosial, ilmu ekonomi dan agama dengan term post Christianity6. Postmodernisme selanjutnya berkembang dalam literature dan arsitektur yang merupakan pusat perdebatan post-modernisme.

J.F Lyotard dalam bukunya La Condition Postmoderne (1979), mengartikan postmodernisme secara sederhana sebagai "incredulity toword metanarratives (ketidakpercayaan terhadap metanarasi). Metanarasi yang dimaksud misalnya kebebasan, kemajuan, emansipasi kaum proletar dan sebagainya. Lyotard adalah filsuf yang memperkenalkan istilah postmodernisme kedalam bidang falsafat. Menurutnya, postmodernisme itu sepertinya adalah sebuah 'intensifikasi dinamisme', upaya tak henti-hentinya untuk mencari kebaruan, eksperimentasi, dan revolusi kehidupan terus. Dengan kata lain dalam bidang filsafat postmodernisme diartikan sebagai "segala bentuk refleksi kritis atas paradigm-paradigma modern dan atas metafisika pada umunya". Terkadang orang menyamakan postmodernisme dengan postmodernitas. Perbedaanya terletak postmodernisme bermakna pemikiran filsafat yang menyeranag modernism dan postmodernitas adalah realitas yang merupakan hasil dari pemikiran yang diproduksi.

Upaya yang dilakukan postmodernisme adalah membongkar dan menghancurkan metanarasi yang dihasilkan dari sebuah ideology dan pemikiran mainstream yang hegemonic dan menguasai kultur pengetahuan masyarakat. Secara bersamaan falsafat postmodern menyalahkan kapitalisme yang eksploitatif dan sosialisme yang birokratik, dan sama-sama dainggap sebagai narasi besar (grand narratives) yang menyebabkan kegersangan bagi dunia sosial modern. Menurut Turner, perkembangan-perkembangan politik dan intelektual dalam postmodernisme menjadi tantangan besar bagi orientalisme.

Teori postmodernisme adalah satu konsekuensi dari obsesi abad ini akan bahasa. Para pemikir abad ke-20 seperti Bertrand Russel, Ludwig 
Wittgenstein, Martin Heidegger dan lainnya menggeser fokus analisis mereka menjauh dari ide-ide dalam pikiran ke bahasa untuk mengekspresikan pikiran. Para failasuf, ahli logika dan ahli bahasa sepertinya menyetujui pernyataan apakah yang membuat pikiran menjadi berarti mereka menjawab 'struktur bahasa'.

\section{Dekontruksi Jasques Derrida}

Jasques Derrida (1930-2004) adalah seorang filsuf Perancis yang dianggap sebagai tokoh penting poststrukturalis-postmodernis. Derrida lahir dalam lingkungan keluarga Yahudi pada 15 Juli 1930 d Aljazair. dan meninggal dunia karena kanker pada tahun 2004. karya awal Derrida dibidang falsafat berkaitan dengan fenomologi. Latihan awalnya sebagai filsuf dilakukan melalui kacamata Edmund Husserlt. Inspirasi penting lain bagi pemikiran awalnya berasal dari Nietzsche, Heidegger, De Saussure, Levinas dan Freud. Derrida mengakui utang budinya kepada para pemikir itu dalam pengembangan pendekatannya terhadap teks, yang kemudian dikenal sebagai "dekonstruksi"

Pemikiran Derrida yang terkenal adalah dkonstruksi. Pada awalnya dekontruksi adalah cara atau metode membaca teks-teks tertentu. Konstruksi ini berkomitmen pada analisis habis-habisan terhadap makna literal teks, dan juga untuk menemukan problemprobleminternal didalam makna tersebut yang mungkin bisa mengarahkan ke makna-makna alternatif, dipojok-pojok teks (termasuk catatan kaki) yang sering diabaikan. Dekontruksi menyatakan bahwa di dalam setiap teks terdapat titik-titik ekuivokasi (pengelakan) dan kemampuan untuk tidak memutuskan yang mengkianati setipa stabilitas makna yang mungkin dimaksudkan oleh si pengarang dalam teks tulisannya.

Untuk memahami dekonstruksi Derrida kita mencoba melacak kronologi pemikirannya. dari stuktruralisme Saussurean yang bernuansa modernitas. Menurut paham strukturalisme, kenyataan tertinggi dari 
realitas adalah struktur. Bila bahasa dilihat secara struktural, bisa disimpulkan bahwa bahasa bisa ada karena adanya sistem perbedaan dan inti dari sistem perbedaan ini adalah oposisi biner (binary opposition), seperti oposisi antara penanda/petanda, ujaran/tulisan, langue/parole. Oposisi biner dalam linguistic ini berjalan seiring dengan hal yang sama dalam tradisi falsafat barat, seperti: makna/bentuk, jiwa/badan dan sebagainya.

Dalam karyanya, Of Grammatology, Derrida berusaha menunjukkan bahwa struktur penulisan dan grama tology lebh penting dan bahkan 'lebih tua' ketimbang yang dianggap sebagai struktur murni kehadiran diri (presence-to-self), yang dicirikan sebagai kekhasan atau keunggulan lisan atau ujaran. Menurut Bambang, pemikiran Derrida menarik kesimpulan radikal Nietzsche, Hurrerl dan Heidege. Dengan poststrukturalis, ia sampai pada gagasan bahwa akhirnya bahasa dan kata-kata adalah kosong belaka dalam artian mereka sebetulnya tidak menunjuk pada suatu apapun selain pada makna itu sendiri. Oposisi binar paling terkemuka yang dibongkar dalam karya awal Derrida adalah ujaran (speech) dan tulisan (writing). Inilah sebabnya mengapa Derrida begitu berlandaskan pada teks, dan mengapa term-term kuncinya selalu berubah, karena selalu tergantung pada siapa atau apa yang ia cari untuk didekonstruksi, sehingga titik pengelakan selalu dilokasikan ditempat yang berbeda.

Dalam kajian keagamaan dekontruksi Derrida memberi beberapa pengaruh penting, pertama berkat dekontruksi Derrida 'makna' tidak lagi dipandang sebagai sesuatu yang mutlak, tunggal, universal, dan stabil, tetapi makna selalu berubah. Klaim-klaim kebenaran absolut, kebenaran universal dan kebenaran tunggal yang biasa mewarnai gaya pemikiran falsafat sebelumnya, semakin digugat, dipertanyakan, dan tidak lagi bisa diterima. kedua, dominasi sebuah diskursus keagamaan atas diskursus keagaaan lainmenandakan adanya sebuah struktur hierarkis penafsiran 
yang menempatkan diskursus keagamaan yang dominan itu pada posisi 'pusat' dan menempatkan diskursus keagamaan lainnya pada posisi 'pinggiran'. Struktur hierarkis ini tidak hanya mengeksklusifkan keagamaan tertentu, tetapi juga menundukkan dan menyubdinasikan. Jadi diperlukan strategi untuk melakukan pembalikan struktur hierarkis penafsiran itu, guna melakukan delegitimasi atas 'pusat' utama' dari diskusus yang dominan. Strategi ini dapat dilakukan dengan memakai dekontruksi (pembongkaran). Ketiga, dekontruksi dapat dipahami sebagaian openness towards the other (keterbukaan kepada yang lain). Pernyataan ini tidak hanya mencirikan karakter yang paling penting dari dekontruksi sebagai sebuah strategi, tapi bisa digunakan sebagai arahan untuk membangun suatu sikap, etos, dan pandangan dunia posma yang egaliter dengan menekankan prinsip koeksistensi antar Bergama entitiasentitas, baik sosial, agama, dan budaya. Dengan demikian dekontruksi seperti juga pendekatan postmodernisme lainnya, cocok dengan konsep pluralitas budaya, agama, dan identitas, pluralitas permainan bahasa, banyaknya wacana, penghargaan terhadap perbedaan dan membuka diri terhadap yang lain (the other). Penghargaan terhadap perbedaan pada pendekatan local, regional, etnik baik pada masalah sejarah, seni, politik, masyarakat dan kebudayaan pada umumnya.

Pendekatatan dekontruksi ini pernah dipakai Derrida sendiri dalam menagnalisis peristiwa 11 September 2001, tiga tahun sebelum beliau wafat. Dialog bersama tokoh postmo Habermas yang kemudian diabadikan dalam bentuk karya publikasi ini berkesimpulan bahwa bagi Derrida terasa latah ketika Amerika memalkumatkan perang terhadap terorisme. Seolah-olah terorisme menjadi konsep yang jelas dan gamblang dan mengandung entitas politik. Derrida menilai, harus ada upaya dekonstruktif terhadap istilah terorisme. Baik Habermas maupun Derrida berpendapat bahwa terorisme adalah istilah yang dimaknai dan diterangkan, Bagi keduanya terasa latah ketika Barat mengampanyekan 
perang terhadap terorisme yang jelas, gamblang, dan dapat dipertanggungjawabkan. Istilah terorisme masih menjadi fenomea yang kompleks, atas dasar apa misalnya terorisme dianggap bermuatan politis? Apakah terorisme sama dengan perang? Apakah terorisme tindakan kriminalitas murni? yang semua ini masih butuh penjelasan dan konsep yang mendasar.

Dalam pemikiran Islam, Muhammed Arkoun dan Hassan Hanafi mencoba mempratekkan metode dekontruksi (pembongkaran) teks-teks keagaman Islam baik tafsir, fiqh maupun kalam. Menurut Arkoun ilmuilmu keislaman tidak cukup dengan hanya menyentuh dimensi normatifmetafisik atau dimensi historis-empiris. Pola pendekatan dikotomis ini memang lebih menyempitkan wilayah telaah keagamaan. Selagi al-Qur'an hanya bermuatan normative, kalam dan falsafat Islam kurang dapat memahami hubungan dialektis dan historisitas Al Qur'an dan normativitasnya, maka akan sulit terjadi shift-ing paradigm (pergeresar paradigma). Dalam the body of knowledge ilmu-ilmu keislaman. Dengan begitu, proses dekontruksi yang menolak segala bentuk kemapanan, kemutlakan, standar baku dan kaku akan menunjukkan adanya dinamika keberagaman manusia dalam arti yang sesungguhnya.

\section{Kesimpulan}

Dari hasil pembahasan di atas maka dapat kita tarik kesimpulan sebagai berikut; Perspektif Konstruksi Sosial Berger dan Luckman dalam tiga macam kontruktivisme yaitu kontruktivisme radikal, realism hipotesis dan kontruktivisme biasa. Dari ketiga macam konstruktivisme, terdapat kesamaan di mana konstruktivisme dilihat sebagai sebuah kerja kognitif individu untuk menafsirkan dunia realitas yang ada karena terjadi relasi sosial antara individu dengan lingkungan atau orang disekitarnya. Individu kemudian membangun sendiri pengetahuan atas realitas yang dilihat itu berdasarkan pada struktur pengetahuan yang telah ada sebelumnya, inilah yang oleh Berger dan Luckmann disebut 
dengan konstruksi sosial. Kontruktivisme radikal memiliki peran dalam penumbuhan paham terorisme dalam keluarga.

Dekontruksi Jasques Derrida dalam fenomena ini adalah proses dekontruksi yang menolak segala bentuk kemapanan, kemutlakan, standar baku dan kaku di masyarakat. Di satu sisi, ini menunjukkan adanya dinamika keberagaman manusia dalam arti yang sesungguhnya. Di sisi lain, ini bisa menumbuhkan sikap intoleransi.

Komunikasi merupaka sebuah proses hubungan antar seseorang dengan yang lainnya. Dalam keluarga dibutuhkan sebuah komunikasi yang baik antara orang tua dan anak baik secara verbal atau non-verbal agar dapat memunculkan sebuah motivasi pada anaknya.

\section{Daftar Pustaka}

Amin Abdulah, 2004, Falsafah Kalam di Era Postmodernisme, Yogyakarta: Pustaka Pelajar.

Bertens, K, 1999, Ringkasan Sejarah Filsafat, Yogyakarata: Kanisius.

Borradori, Memahami peristiwa 11/9 bersama Derrida dan Habermas, diakses dari http//www.khkssk

Budi Hardiman F, 2007, Filsafat Fragmentaris, Yogyakarta: Kanisius

https://nasional.tempo.co/read/1037310/bnpt-potensi-radikalismemasyarakatindonesia-perlu-diwaspadai

https://www.liputan6.com/news/read/3582361/survei-41-masjid-dikantorpemerintahan-terindikasi-sebar-radikalisme http://www.bbc.com/indonesia/indonesia-44357353

Journal of Advancead Scientific Research and Management. Vol 22017.

Laufer, Avital, 2017, Children's Emotional and Behavioral Problems in The Shadow of Terrorism: The Case of Israel. Mally Shechory Bitton, Department of Criminology, Ariel University Israel.

Merrilees, Christine E, 2018, The Role of Emotional Security, Narrative, and Resilience for Youth and Families in ContextsOf Armed Conflict, Family Court Review, Volume: Vol 56 No 2.

Milton Hunnex. D, 2004, Peta Filsafat, Jakarta Selatan: Mizan Publika. 
Norris, Christopher, 2008, Membongkat Teori Dekontruksi Jasques Derrida, Yogyakarata, Ar-Ruzz Media.

Polomo, Margaret M, 2004, Sosiologi Kotemporer, Jakarta: Raja Gravindo Persada.

Puspitawati Harien, 2012, Konsep dan Teori Keuarga, Bogor: PT IPB Press.

Richard, 2012, Mengenal Postmodernisme, Jakarta: Jalasutra.

Suparno, Paul, 1997, Filsafat Kontruktivisme dalam Pendidikan, Yogyakarta: Kanisius.

Taib, Roslizawati, Political Particaption: Radical Young People in Malaysia, International.

Tangir, Gali, 2017, Children's Ajustment in a Climate of Political Violence: Comparing Mother and Child Reports. CrossMark Springer Science and Bisness, Media LLC. 